\title{
Novel Protozoans in Austria Revealed through the Use of Dogs as Sentinels for Ticks and Tick-Borne Pathogens
}

\author{
Michiel Wijnveld ${ }^{1, *(\mathbb{D})}$, Anna-Margarita Schötta ${ }^{1}\left(\mathbb{D}\right.$, Theresa Stelzer ${ }^{1}$, Georg Duscher ${ }^{2,3}$, Michael Leschnik ${ }^{4}$, \\ Hannes Stockinger ${ }^{1}{ }^{(\mathbb{D}}$, Per-Eric Lindgren ${ }^{5,6}$ and Gerold Stanek ${ }^{1}$
}

1 Institute for Hygiene and Applied Immunology, Center for Pathophysiology, Infectiology and Immunology, Medical University of Vienna, Kinderspitalgasse 15, 1090 Vienna, Austria; anna-margarita.schoetta@meduniwien.ac.at (A.-M.S.); theresa.stelzer@meduniwien.ac.at (T.S.); hannes.stockinger@meduniwien.ac.at (H.S.); gerold.stanek@meduniwien.ac.at (G.S.)

2 Department of Pathobiology, Institute of Parasitology, University of Veterinary Medicine Vienna, Veterinärplatz 1, 1210 Vienna, Austria; georg.duscher@ages.at

3 AGES-Austrian Agency for Health and Food Safety, Spargelfeldstrasse 191, 1220 Vienna, Austria

4 Small Animal Clinic, Department for Companion Animals, University of Veterinary Medicine Vienna, Veterinärplatz 1, 1210 Vienna, Austria; michael.leschnik@vetmeduni.ac.at

5 Division of Inflammation and Infection, Department of Biomedical and Clinical Sciences, Linköping University, SE-581 85 Linköping, Sweden; per-eric.lindgren@liu.se

6 Division of Clinical Microbiology, Laboratory Medicine, Region Jönköping County, SE-551 85 Jönköping, Sweden

Citation: Wijnveld, M.; Schötta, A.-M.; Stelzer, T.; Duscher, G.; Leschnik, M.; Stockinger, H.; Lindgren, P.-E.; Stanek, G. Novel Protozoans in Austria Revealed through the Use of Dogs as Sentinels for Ticks and Tick-Borne Pathogens. Microorganisms 2021, 9, 1392. https:// doi.org/10.3390/microorganisms 9071392

Academic Editors: Gabriele Margos, Volker Fingerle, Anna J. Henningsson and Mateusz Markowicz

Received: 10 June 2021

Accepted: 24 June 2021

Published: 28 June 2021

Publisher's Note: MDPI stays neutral with regard to jurisdictional claims in published maps and institutional affiliations.

Copyright: () 2021 by the authors. Licensee MDPI, Basel, Switzerland. This article is an open access article distributed under the terms and conditions of the Creative Commons Attribution (CC BY) license (https:// creativecommons.org/licenses/by/ $4.0 /)$.
* Correspondence: michiel.wijnveld@meduniwien.ac.at; Tel.: +43-1-40160-33094

\begin{abstract}
We previously isolated and cultivated the novel Rickettsia raoultii strain Jongejan. This prompted us to ask whether this strain is unique or more widely present in Austria. To assess this issue, we retrospectively screened ticks collected from dogs in 2008. Of these collected ticks, we randomly selected 75 (47 females and 28 males) Dermacentor reticulatus, 44 ( 21 females, 7 males, and 16 nymphs) Haemaphysalis concinna, and 55 (52 females and 3 males) ticks of the Ixodes ricinus complex. Subsequently, these ticks were individually screened for the presence of tick-borne pathogens using the reverse line blot hybridization assay. In our current study, we detected DNA from the following microbes in D. reticulatus: Anaplasma phagocytophilum, Borrelia lusitaniae, Borrelia spielmanii, Borrelia valaisiana, and $R$. raoultii, all of which were $R$. raoultii strain Jongejan. In H. concinna, we found DNA of a Babesia sp., Rickettsia helvetica, and an organism closely related to Theileria capreoli. Lastly, I. ricinus was positive for Anaplasma phagocytophilum, Borrelia afzelii, Borrelia burgdorferi sensu stricto, Borrelia garinii/Borrelia bavariensis, B. lusitaniae, B. spielmanii, B. valaisiana, Candidatus Neoehrlichia mikurensis, Rickettsia helvetica, Rickettsia monacensis, and Theileria (Babesia) microti DNA. The detection of DNA of the Babesia sp. and an organism closely related to Theileria capreoli, both found in H. concinna ticks, is novel for Austria.
\end{abstract}

Keywords: Anaplasma; Babesia; Borrelia; Neoehrlichia; Rickettsia; Theileria; Austria; dogs; Ixodes ricinus; Dermacentor reticulatus; Haemaphysalis concinna

\section{Introduction}

In a previous study, we isolated and cultivated the novel Rickettsia raoultii strain Jongejan from Austrian Dermacentor reticulatus ticks [1]. Rickettsia raoultii belongs to the spotted fever group rickettsiae and can cause Dermacentor-borne necrotic erythema and lymphadenopathy (DEBONEL), tick-borne lymphadenopathy (TIBOLA), and scalp eschar and neck lymphadenopathy (SENLAT) in humans [2]. The main vectors of $R$. raoultii are Dermacentor ticks, specifically D. reticulatus and D. marginatus [3], but occasionally, (DNA of) $R$. raoultii is detected within other tick species, of which the vector capacity must still be investigated and confirmed $[4,5]$. 
Rickettsiae, including $R$. raoultii, are considered emerging tick-borne pathogens with their vector ticks expanding to novel loci worldwide, particularly in Europe [6,7]. Rickettsiosis is often an underdiagnosed disease, and many aspects are neglected [8]. With the isolation of a molecularly distinct $R$. raoultii strain, the question was raised whether this isolate is unique or whether this strain is more widely present within Austrian ticks. To assess this issue, a retrospective study was conducted to screen ticks collected from dogs in a previous study [9]. We chose to screen these ticks as this would enable us to cover a large area throughout most of the year. Additionally, to acquire a broad overview of tick-borne microbes present within the study area, we analyzed the collected ticks using the reverse line blot (RLB) assay. This enabled us to simultaneously screen for the presence of a large panel of tick-borne microorganisms, including $R$. raoultii strain Jongejan. Using this method, we obtained an extensive impression of tick-borne pathogens of the genera Anaplasma, Babesia, Borrelia, Neoehrlichia, Rickettsia, and Theileria present within the study area.

\section{Materials and Methods}

\subsection{Ticks}

The ticks were collected during a previous study conducted in 2008 [9]. Throughout that study, ticks were collected from dogs on a daily basis. The dogs were walked in an area east of Vienna, Austria $\left(48^{\circ} 6^{\prime} 54^{\prime \prime} \mathrm{N} 16^{\circ} 42^{\prime} 9^{\prime \prime} \mathrm{E} ; 48^{\circ} 17^{\prime} 56^{\prime \prime} \mathrm{N} 16^{\circ} 49^{\prime} 49^{\prime \prime} \mathrm{E} ; 47^{\circ} 55^{\prime} 2^{\prime \prime} \mathrm{N}\right.$ $16^{\circ} 36^{\prime} 50^{\prime \prime} \mathrm{E} ; 47^{\circ} 51^{\prime} 51^{\prime \prime} \mathrm{N} \mathrm{16} 6^{\circ} 50^{\prime} 56^{\prime \prime} \mathrm{E}$; https: / / www.google.com/maps/d/edit?mid=1ZT2 orCQfXxZJUNUZmEaYWSMQIn5S9-7N\&usp) (Figure 1). All ticks, in various stages of engorgement, were morphologically identified and stored individually at $-20{ }^{\circ} \mathrm{C}$ until later use. As the molecular identification and/or confirmation of Ixodes ricinus ticks remained inconclusive, we refer to these ticks as part of the I. ricinus complex. Of these ticks, 75 (47 females and 28 males) D. reticulatus, 44 (21 females, 7 males, and 16 nymphs) Haemaphysalis concinna, and 55 (52 females and 3 males) ticks of the I. ricinus complex were randomly selected for molecular analysis.

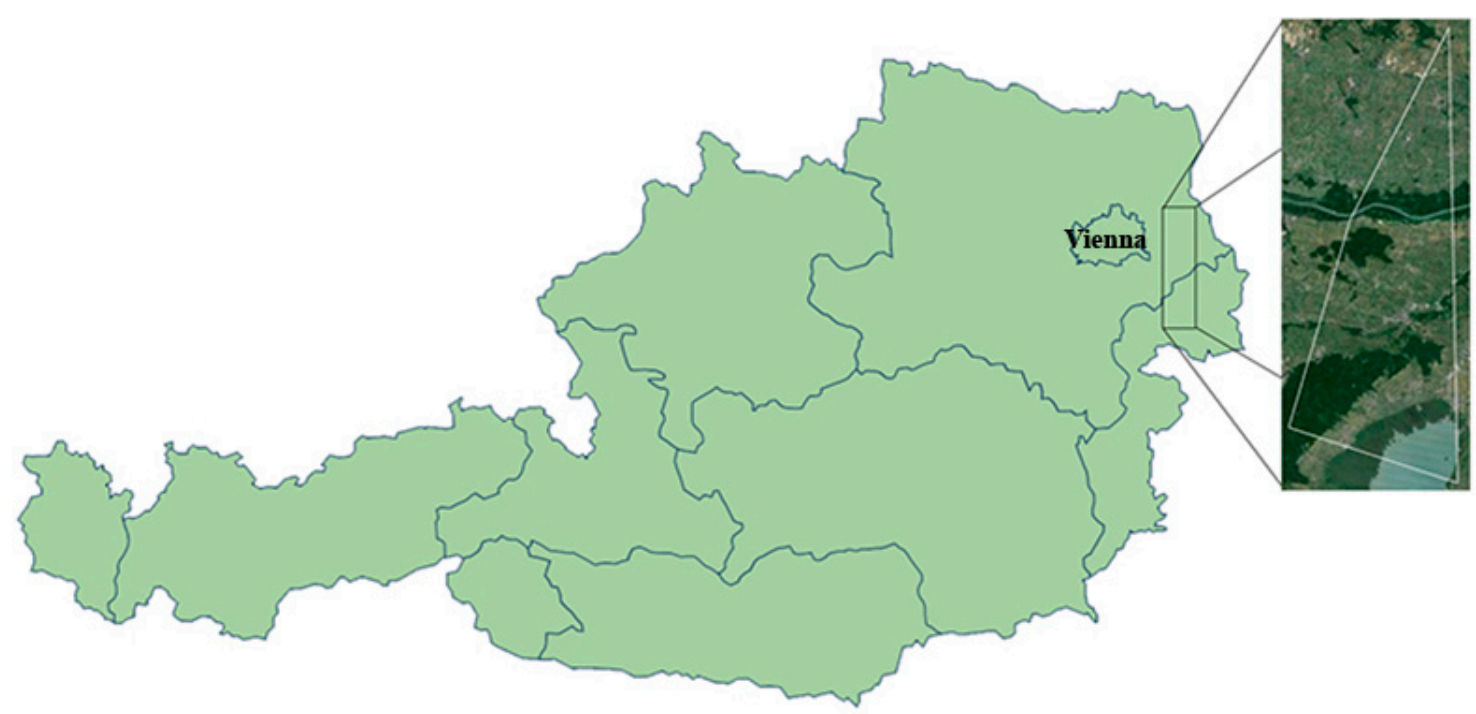

Figure 1. Map of Austria. The study site is shown in the satellite image excerpt, bordered in white. The map is modified from Google Maps.

\subsection{DNA Extraction}

DNA was extracted from the ticks by applying the Qiagen DNeasy Blood \& Tissue Kit (Qiagen, Hilden, Germany). Briefly, individual ticks were cut in halves or quarters, depending on their size and using a sterile scalpel blade per individual tick, and homogenized in sterile $1.5 \mathrm{~mL}$ microcentrifuge tubes filled with $180 \mu \mathrm{L}$ ATL buffer using disposable pestles (Bel-Art Products, VWR, Vienna, Austria). The lysis step was performed overnight at $56{ }^{\circ} \mathrm{C}$. 
The remaining steps were carried out according to the manufacturer's instructions. The DNA extractions obtained were stored at $-20^{\circ} \mathrm{C}$ until further use.

\subsection{Reverse Line Blot-PCR}

Several genus-specific RLB-PCRs were carried out as previously described $[1,4]$ using the biotinylated primers listed in Table 1 . The PCR reaction mix (25 $\mu \mathrm{L}$ total volume) contained $5 \mu \mathrm{L}(5 \times)$ of Phire reaction buffer, $200 \mathrm{nmol} / \mathrm{L}$ of each dNTP (Solis BioDyne, Tartu, Estonia), $400 \mathrm{nmol} / \mathrm{L}$ of each primer per specific primer pair, 0.125 units of Phire Hot Start II DNA Polymerase (Thermo Scientific, Vienna, Austria), $2.5 \mu \mathrm{L}$ of template DNA, and PCR-grade water (Sigma-Aldrich, Vienna, Austria). Several touchdown PCR protocols were used as described previously [1,4]. The resulting amplicons were analyzed using RLB hybridization as described previously [4].

Table 1. Primers used for the reverse line blot and sequencing.

\begin{tabular}{|c|c|c|c|}
\hline Target Organisms & Sequence $\left(5^{\prime}-3^{\prime}\right)$ & Target Region & Reference \\
\hline \multicolumn{4}{|l|}{ RLB primers * } \\
\hline \multirow{2}{*}{ Anaplasma/Ehrlichia spp. } & GGAATTCAGAGTTGGATCMTGGYTCAG & \multirow{2}{*}{ 16S ribosomal RNA gene } & [10] \\
\hline & $\begin{array}{c}\text { (Biotin-)CGGGATCCCGAGTTT } \\
\text { GCCGGGACTTYTTCT }\end{array}$ & & [11] \\
\hline \multirow{2}{*}{ Babesia/Theileria spp. } & GACACAGGGAGGTAGTGACAAG & \multirow{2}{*}{$18 \mathrm{~S}$ ribosomal RNA gene } & [12] \\
\hline & (Biotin-)CTAAGAATTTCACCTCTGACAGT & & [12] \\
\hline \multirow{2}{*}{ Borrelia burgdorferi sensu lato } & ACCATAGACTCTTATTACTTTGACCA & \multirow{2}{*}{$\begin{array}{l}\text { 5S-23S ribosomal RNA } \\
\text { intergenic spacer }\end{array}$} & [13] \\
\hline & (Biotin-)GAGAGTAGGTTATTGCCAGGG & & [13] \\
\hline \multirow{4}{*}{ Rickettsia spp. } & GAACGCTATCGGTATGCTTAACACA & \multirow{2}{*}{ 16S ribosomal RNA gene } & {$[14,15]$} \\
\hline & (Biotin-)CATCACTCACTCGGTATTGCTGGA & & {$[14,15]$} \\
\hline & GATAGGTCRGRTGTGGAAGCAC & \multirow{2}{*}{$\begin{array}{l}\text { 23S-5S ribosomal RNA } \\
\text { intergenic spacer }\end{array}$} & [16] \\
\hline & (Biotin-)TCGGGAYGGGATCGTGTGTTTC & & [16] \\
\hline \multicolumn{4}{|l|}{ Additional sequencing primers } \\
\hline \multirow{8}{*}{ Rickettsia spp. } & ATGAGTAAAGACGGTAACCT & \multirow[b]{2}{*}{ sca4 } & [17] \\
\hline & AAGCTATTGCGTCATCTCCG & & [17] \\
\hline & ATGGCGAATATTTCTCCAAAA & \multirow{2}{*}{ ompA } & [18] \\
\hline & GTTCCGTTAATGGCAGCATCT & & [18] \\
\hline & AAACAATAATCAAGGTACTGT & \multirow{2}{*}{ ompB } & [19] \\
\hline & TACTTCCGGTTACAGCAAAGT & & [19] \\
\hline & GCAAGTATCGGTGAGGATGTAAT & \multirow{2}{*}{ glt $A$} & [20] \\
\hline & GCTTCСТTAAAATTCAATAAATCAGGAT & & {$[20]$} \\
\hline \multirow{2}{*}{$\begin{array}{l}\text { Molecular identification of } \\
\text { ticks }\end{array}$} & CTGCTCAATGATTTTTTAAATTGCTGTGG & \multirow[t]{2}{*}{ 16S ribosomal RNA gene } & [21] \\
\hline & CCGGTCTGAACTAGATCAAGT & & [22] \\
\hline
\end{tabular}

* The RLB-PCRs were conducted with biotinylated reverse primers. Nonbiotinylated primers were used for sequencing.

\subsection{Molecular Confirmation of Morphological Identification of Ixodes Ricinus}

To confirm the morphological identification of I. ricinus complex ticks, we amplified part of the 16S rRNA gene as previously described [21,22] using the primers shown in Table 1. The resulting amplicons were sent to Microsynth (Balgach, Switzerland) for bidirectional sequencing. Morphological identification of I. ricinus complex ticks is difficult after the discovery of Ixodes inopinatus [23] due to the large similarities between these species and the fact that they inhabit the same geographical areas. The consensus sequences obtained were analyzed, and unique sequences were submitted to GenBank at the National Center for Biotechnology Information (NCBI) (http:/ / www.ncbi.nlm.nih.gov/genbank/). The sequences can be accessed by using the accession numbers MW666053 and MW666054.

\subsection{Sequencing}

The RLB uses a set of 43 different oligonucleotide probes per membrane, upon which the PCR products are hybridized. This panel of oligonucleotide probes consists of a mixture of genus- and species-specific probes [4]. As there is limited space per membrane, we used the genus-specific probes as a backup should we fail to detect a species-specific signal. 
The genus-specific probes can be considered "catch-all" probes. When any of these catchall signals were observed without a species-specific signal, we sequenced the RLB-PCR amplicon. Further sequencing was also used to confirm the presence of $R$. raoultii strain Jongejan. For this purpose, we sequenced the rickettsial $\operatorname{omp} A, \operatorname{omp} B, s c a 4, g l t A$, and $16 \mathrm{~S}$ rRNA genes and the 23S-5S rRNA intergenic spacer (IGS).

All PCR reactions for sequencing were conducted with nonbiotinylated primers (Table 1) and an increased polymerase concentration. The PCR mixtures (25 $\mu \mathrm{L}$ total volume) were identical as previously mentioned. However, we used 0.5 units instead of 0.125 units of Phire Hot Start II DNA Polymerase (Thermo Scientific, Vienna, Austria). The resulting PCR fragments were analyzed on agarose gels, excised, and purified by applying a gel purification kit (QIAquick Gel Extraction Kit, Qiagen, Hilden, Germany). Purified rickettsial PCR amplicons were sent to Microsynth (Balgach, Switzerland) for bidirectional sequencing. To obtain longer sequences, the purified "catch-all-only" RLB-PCR fragments were cloned into the cloning vector PJET1.2 according to the respective kit instructions (CloneJET PCR Cloning Kit, Thermo Fisher Scientific, Vienna, Austria). The obtained constructs were used to transform Escherichia coli DH5 $\alpha$ cells. Plasmids were isolated from overnight cultures of the transformed E. coli cells using a plasmid purification kit (GeneJET Plasmid Miniprep Kit, Thermo Fisher Scientific, Vienna, Austria) as described in the manual. The purified plasmids were sent for bidirectional sequencing to Microsynth (Balgach, Switzerland) using the pJET1.2 forward and reverse sequencing primers.

The obtained sequences were truncated when required (plasmid and primer regions removed). The consensus sequences were analyzed, and unique sequences were submitted to GenBank (http:/ / www.ncbi.nlm.nih.gov/genbank/), which are accessible using the accession numbers MW646028-MW646032.

\section{Results}

\subsection{Identification of Ixodes Ticks by Sequencing}

Sequencing part of the 16S rRNA gene resulted in two distinctive sequences (MW666053 and MW666054). Sequence MW666053 is $99.15 \%$ to $100 \%$ similar to I. ricinus (KM211785KM211788) and 98.58\% and 98.87\% similar to I. inopinatus (KM211789 and KM211789, respectively). Sequence MW666054 is $98.31 \%$ to $98.87 \%$ similar to I. ricinus (KM211785KM211788) and 99.44\% similar to I. inopinatus (KM211789 and KM211789).

\subsection{Molecular Detection of Tick-Borne Microorganisms}

The DNA of a large variety of tick-borne microorganisms was detected using RLB and subsequent sequencing (Table 2). The most abundant organisms were of the genus Rickettsia with 16 positive ticks. Ten ticks were positive for $R$. raoultii, 5 ticks were positive for $R$. helvetica, and $R$. monacensis was detected in 1 tick. The second most frequently detected organisms belonged to the Borrelia burgdorferi sensu lato complex. A total of 13 ticks were positive, 4 ticks were positive with $B$. valaisiana, and 3 ticks with B. lusitaniae. B. spielmanii and $B$. afzelii were both detected in 2 ticks. Lastly, B. burgdorferi sensu stricto and B. garinii/B. bavariensis were detected in 1 tick (the methods applied failed to discriminate between B. garinii and B. bavariensis). The third most often identified genus was Anaplasma with 6 ticks positive for A. phagocytophilum. The fourth most frequently detected genus was Babesia in 4 ticks. Subsequent sequencing of the 18S rRNA gene fragment used for RLB revealed that all 4 ticks (MW646028-MW646031) were positive for a Babesia sp. closely related to Babesia spp. detected in the Russian regions Amur, Irkutsk, and Khabarovsk (99.72\% to 100\% similarity with KJ486560.1, KJ486562.1, KJ486563.1, KJ486564.1, KJ486566.1, KJ486567.1, and KJ486568.1). Theileria spp. DNA was present in 2 ticks, 1 tick was positive for T. (Babesia) microti, and additional sequencing revealed that the second tick (MW646032) was positive for DNA closely related to T. capreoli DNA (99.74\% similarity with MH085202.1 and DQ866842.1) previously detected in Spain and China, respectively. Finally, a single tick was positive for Candidatus Neoehrlichia mikurensis. 
Table 2. Tick-borne microorganism DNA detected in ticks collected from dogs.

\begin{tabular}{|c|c|c|c|c|c|c|c|c|c|c|}
\hline & \multicolumn{3}{|c|}{ Dermacentor reticulatus } & \multicolumn{4}{|c|}{ Haemaphysalis concinna } & \multicolumn{3}{|c|}{ Ixodes ricinus } \\
\hline & $\begin{array}{c}\text { Tot. } \\
(n=75)\end{array}$ & $\begin{array}{l}\text { Female } \\
(n=47)\end{array}$ & $\begin{array}{c}\text { Male } \\
(n=28)\end{array}$ & $\begin{array}{c}\text { Tot. } \\
(n=44)\end{array}$ & $\begin{array}{l}\text { Female } \\
(n=21)\end{array}$ & $\begin{array}{c}\text { Male } \\
(n=7)\end{array}$ & $\begin{array}{l}\text { Nymphs } \\
(n=16)\end{array}$ & $\begin{array}{c}\text { Tot. } \\
(n=75)\end{array}$ & $\begin{array}{l}\text { Female } \\
(n=47)\end{array}$ & $\begin{array}{c}\text { Male } \\
(n=28)\end{array}$ \\
\hline Anaplasma phagocytophilum & 5 & 1 & 4 & & & & & 1 & 1 & \\
\hline Babesia spp. & & & & 4 & & 2 & 2 & & & \\
\hline Borrelia afzelii & & & & 1 & & & 1 & 1 & 1 & \\
\hline Borrelia burgdorferi sensu stricto & & & & & & & & 1 & 1 & \\
\hline $\begin{array}{c}\text { Borrelia garinii/Borrelia } \\
\text { bavariensis }\end{array}$ & & & & & & & & 1 & 1 & \\
\hline Borrelia lusitaniae & 2 & & 2 & & & & & 1 & 1 & \\
\hline Borrelia spielmanii & 1 & 1 & & & & & & 1 & 1 & \\
\hline Borrelia valaisiana & 3 & 2 & 1 & & & & & 1 & 1 & \\
\hline Ca. Neoehrlichia mikurensis & & & & & & & & 1 & & 1 \\
\hline Rickettsia helvetica & & & & 2 & & 1 & 1 & 3 & 2 & 1 \\
\hline Rickettsia monacensis & & & & & & & & 1 & 1 & \\
\hline Rickettsia raoultii & 10 & 1 & 9 & & & & & & & \\
\hline Theileria capreoli & & & & 1 & & & 1 & & & \\
\hline Theileria (Babesia) microti & & & & & & & & 1 & 1 & \\
\hline
\end{tabular}

\subsection{Rickettsia raoultii Sequencing}

Ten ticks tested positive for $R$. raoultii DNA by RLB (Table 2). To test which $R$. raoultii strain was present within these ticks, several genes were amplified and subsequently sequenced. After analysis, all $R$. raoultii sequences obtained were $100 \%$ identical to the $R$. raoultii strain Jongejan sequences, with a special emphasis on the sca4 gene and the 23S-5S rRNA IGS. The sca4 gene and the IGS region are most notably different between $R$. raoultii strain Jongejan and other $R$. raoultii strains. Specifically, the sca4 gene turned into a pseudogene by a single nucleotide inclusion, and there was a 50-base pair deletion in the 23S-5S rRNA IGS.

\section{Discussion and Conclusions}

\subsection{Tick Collecting}

There are several methods for collecting ticks from the environment, including flagging/dragging [24], carbon dioxide trapping [25], and collecting ticks directly from the vegetation [1]. All these methods have their own benefits but are labor-intensive, especially when areas would be sampled every day. A study conducted in 2008 [9] showed that dogs prove to be a valuable resource for the collection of ticks in a large region with the possibility of obtaining ticks on a daily basis. Screening ticks collected from a host, it should be noted that the prevalence numbers of the observed microorganisms are biased. In general, it is impossible to determine whether the screened tick was positive for a specific pathogen prior to or following the blood meal during which the tick was collected. Additionally, infection of naïve ticks through cofeeding with positive ticks on the same host plays a significant role [26]. During cofeeding, microbes transmitted by positive ticks are able to infect naïve ticks without requiring the host animal to be (systemically) infected [26]. Therefore, overall tick-borne pathogen prevalence cannot be used for meaningful analysis. However, the presence of certain tick-borne microbes within the study area can still be confirmed this way.

\subsection{Molecular Identification of Ixodes Ticks}

The morphological identification of I. ricinus complex ticks is difficult, and molecular confirmation by sequencing the $16 \mathrm{~S}$ rRNA gene is advisable. Estrada-Peña and colleagues [23] described the morphological characteristics and molecular sequences of the 16S rRNA gene belonging to both I. ricinus and I. inopinatus. The similarity between I. ricinus (KM211785-KM211788) and I. inopinatus (KM211789 and KM211789) 16S rRNA is $98.47 \%$ to $99.23 \%$. As mentioned in the results section, our obtained sequence MW666053 is 99.15\% to $100 \%$ similar to I. ricinus (KM211785-KM211788) and 98.58\% and 98.87\% similar to I. inopinatus (KM211789 and KM211789, respectively). Sequence MW666054 is $98.31 \%$ to $98.87 \%$ similar to I. ricinus (KM211785-KM211788) and 99.44\% similar to I. inopinatus (KM211789 and KM211789). We therefore consider ticks with sequence MW666053 to be- 
long to $I$. ricinus sensu stricto. However, ticks with the 16S rRNA gene sequence MW666054 are difficult to place as neither I. ricinus nor I. inopinatus $16 S$ rRNA sequences are closely similar. We therefore refrain from precisely identifying our screened I. ricinus and rather refer to these ticks as belonging to the larger I. ricinus complex.

\subsection{Tick-Borne Microorganisms Screening}

Most of the detected microorganisms had previously been detected in Austria and the surrounding countries $[4,27,28]$. This proves that the applied approach for screening ticks collected from dogs is a useful method for screening for the occurrence of microbes in the environment.

Anaplasma phagocytophilum is usually detected in $0.7 \%$ to $33.9 \%$ of the questing ticks, with a highly diverse prevalence between countries [4,29-31]. Clinical cases are sporadically presented in Austria [32]. Spirochetes of the B. burgdorferi sensu lato complex are seen in ticks in similarly large varying numbers in Europe (i.e., between 8.6\% and 25.6\%) [4,33,34]. However, Dermacentor spp. and Haemaphysalis spp. ticks are not often linked to B. burgdorferi sensu lato spirochetes [35]. To the best of our knowledge, H. concinna is not known to be infected with B. afzelii. Regarding D. reticulatus and D. marginatus, only a few authors have described (the DNA of) B. burgdorferi sensu lato spirochetes in these ticks [36,37]. Therefore, identifying the DNA of these spirochetes in D. reticulatus ticks in this study is remarkable. Additionally, B. lusitaniae and B. valaisiana are mostly associated with (ticks collected from) lizards [38] or birds [39], respectively. This makes the detection of the DNA of these Borrelia spp. in D. reticulatus even more interesting, as both birds and reptiles are only rarely infested by D. reticulatus ticks [35]. However, as the ticks were collected from dogs, we cannot rule out that the dogs were positive but asymptomatic or whether only DNA was present within the ticks and no viable spirochetes. Nevertheless, our findings, in combination with the results of other studies, definitely validate additional research into the B. burgdorferi sensu lato vector capacity by Dermacentor ticks. Candidatus Neoehrlichia mikurensis is a relatively newly discovered human pathogen that was recently cultivated for the first time [40]. This pathogen is detected in ticks at $0.5 \%$ to $4.3 \%$ [4,41] and in some locations at even up to $25.5 \%$ [42]. Detection of Theileria (Babesia) microti in Ixodes ticks is of high medical relevance, especially as T. (Babesia) microti is the major causative agent of human babesiosis in Europe alongside Babesia divergens and Babesia venatorum [43]. This fact is of particular importance for blood banks. Blood from chronically infected asymptomatic blood donors may infect persons if not thoroughly screened for the presence of piroplasms prior to blood transfusion [44]. Infection with T. (Babesia) microti through blood transmission can cause severe complications and death in about a fifth of the cases [44]. Because of its rare occurrence, babesiosis as an infection is often not considered and thus underdiagnosed. Theileria (Babesia) microti is an organism that does not fit to the Babesia or Theileria genera on a molecular basis (18S rRNA) [45]. Additionally, T. (Babesia) microti is not transovarially transmittable, and the occurrence of schizogony in lymphocytes has been observed. Therefore, the pathogen cannot be classified as a Babesia sp. and, for the time being, is instead classified as a Theileria sp. [45]. Rickettsiae are among the most prevalent microorganisms in ticks, including the tick species studied in this paper, and often are considered tick endosymbionts [46]. Prevalence percentages ranging between $16.8 \%$ and $33.7 \%$ for rickettsiae in ticks are not uncommon $[4,41,47]$, and some studies have even shown higher rates of up to $58 \%$ infected ticks [48].

Lastly and most importantly, throughout the previous study in 2008 [9], no symptoms of tick-borne diseases were witnessed in the dogs that participated.

\subsection{Rickettsia raoultii Strain Jongejan}

One of the reasons that the current study was carried out was to see whether the $R$. raoultii strain Jongejan that we isolated in 2016 [1] was unique or more widely present in Austria. To this end, we sequenced the $\operatorname{omp} A, \operatorname{omp} B, s c a 4$, glt $A$, and 16S rRNA genes and the 23S-5S rRNA IGS region of all $R$. raoultii-positive ticks. Sequencing revealed that all $R$. 
raoultii sequences obtained were $100 \%$ identical to the previously isolated and characterized $R$. raoultii strain (KX500092-KX500097). Thus, we were able to confirm that $R$. raoultii strain Jongejan was widely present in the study area in as early as 2008. Further research is required to determine whether $R$. raoultii strain Jongejan possesses additional molecular alterations and perhaps fits into an evolutionary niche, especially as it was unexpected to find no other strain than $R$. raoultii strain Jongejan in this region.

\subsection{Theileria capreoli}

In the course of this study, we detected a Theileria sp. closely related to T. capreoli in a $H$. concinna nymph. The sequences found were $99.74 \%$ similar to $T$. capreoli sequences observed in the Heilongjiang Province, northeastern China (MH085202.1), and in northern Spain (DQ866842.1). The vector tick has not yet been determined for this Theileria sp. Interestingly, in Hungary, stable flies (Stomoxys calcitrans) showed positivity for T. capreoli DNA without reservoir animals (e.g., cervids) being in close proximity [49].

In several studies, wild cervids and bovids were identified carriers of T. capreoli. Among these cervids were fallow deer (Dama dama), red deer (Cervus elaphus), roe deer (Capreolus capreolus), Siberian roe deer (Capreolus pygargus), and bovids such as mouflon (Ovis gmelini) [50-52]. An interesting exception to these findings was shown in a paper describing a study in Croatia, in which T. capreoli was detected in gray wolves (Canis lupus) [53]. This suggests that T. capreoli infections may not be limited to cervids only. Furthermore, if wolves can become positive, the question of whether dogs may become asymptomatic carriers as well arises. Looking further into this, we identified one study in which the researchers had detected the DNA of T. capreoli in the myocardial tissue of a single dog during postmortem diagnostic screening [54]. (The dog died from septic shock complicated by disseminated intravascular coagulation.) This could shed new light on the Hungarian findings of positive stable flies in the absence of natural hosts and the presence of dogs, especially as stable flies are known to bite dogs when they are in close proximity to the stables [55].

\subsection{Babesia spp.}

Our findings also include the detection of babesial sequences closely related to Babesia spp. detected in a Russian study in the Amur, Irkutsk, and Khabarovsk regions (99.72\% to 100\% similarity with KJ486560.1, KJ486562.1, KJ486563.1, KJ486564.1, KJ486566.1, KJ486567.1, and KJ486568.1). Further studies are required to investigate the specific Babesia spp. and the impact they have on human and wildlife health, especially as new Babesia spp. are frequently discovered and the incidence of human babesiosis cases has increased significantly over the past decade [56]. Haemaphysalis concinna is a suspected vector of piroplasms $[57,58]$, the primary hosts of which have been identified in several studies as smalland medium-sized mammals and birds [59-62]. However, H. concinna of all life stages can also be found in larger animals, such as wild and domesticated ungulates [63], and carnivores such as foxes and dogs $[60,64]$. Humans are occasionally bitten by H. concinna as well [27], making $H$. concinna a tick species of high medical importance that requires further study.

Author Contributions: Conceptualization, M.W.; methodology, M.W., A.-M.S. and T.S.; validation, M.W.; formal analysis, M.W., A.-M.S. and T.S.; investigation, M.W.; resources, G.D., M.L. and G.S.; data curation, M.W. and A.-M.S.; writing-original draft preparation, M.W.; writing-review and editing, M.W., A.-M.S., T.S., G.D., M.L., H.S., P.-E.L. and G.S.; visualization, M.W.; supervision, H.S., P.-E.L. and G.S.; project administration, M.W.; funding acquisition, H.S. and G.S. All authors have read and agreed to the published version of the manuscript.

Funding: This research was funded by the European Union's Horizon 2020 research and innovation program, grant number 720480-ID-LYME.

Institutional Review Board Statement: Not applicable.

Informed Consent Statement: Not applicable. 
Data Availability Statement: Unique sequences have been deposited at NCBI's GenBank and are available using the accession numbers MW646028-MW646032, MW666053, and MW666054. Other data are available upon request.

Conflicts of Interest: The authors declare no conflict of interest.

\section{References}

1. Wijnveld, M.; Schötta, A.-M.; Pintér, A.; Stockinger, H.; Stanek, G. Novel Rickettsia raoultii strain isolated and propagated from Austrian Dermacentor reticulatus ticks. Parasites Vectors 2016, 9, 567. [CrossRef]

2. Portillo, A.; Santibáñez, S.; García-Álvarez, L.; Palomar, A.M.; Oteo, J.A. Rickettsioses in Europe. Microbes Infect. 2015, 17, 834-838. [CrossRef]

3. Mediannikov, O.; Matsumoto, K.; Samoylenko, I.; Drancourt, M.; Roux, V.; Rydkina, E.; Davoust, B.; Tarasevich, I.; Brouqui, P.; Fournier, P.E. Rickettsia raoultii sp. nov., a spotted fever group rickettsia associated with Dermacentor ticks in Europe and Russia. Int. J. Syst. Evol. Microbiol. 2008, 58, 1635-1639. [CrossRef]

4. Schötta, A.-M.; Wijnveld, M.; Stockinger, H.; Stanek, G. Approaches for Reverse Line Blot-Based Detection of Microbial Pathogens in Ixodes ricinus Ticks Collected in Austria and Impact of the Chosen Method. Appl. Environ. Microbiol. 2017, 83, e00489-17. [CrossRef] [PubMed]

5. Chmielewski, T.; Podsiadly, E.; Karbowiak, G.; Tylewska-Wierzbanowska, S. Rickettsia spp. In ticks, Poland. Emerg. Infect. Dis. 2009, 15, 486-488. [CrossRef]

6. Piotrowski, M.; Rymaszewska, A. Expansion of tick-borne rickettsioses in the world. Microorganisms 2020, 8, 1906. [CrossRef] [PubMed]

7. Buczek, W.; Koman-Iżko, A.; Buczek, A.; Buczek, A.; Bartosik, K.; Kulina, D.; Ciura, D. Spotted fever group rickettsiae transmitted by Dermacentor ticks and determinants of their spread in Europe. Ann. Agric. Environ. Med. 2020, 27, 505-511. [CrossRef] [PubMed]

8. Tomassone, L.; Portillo, A.; Nováková, M.; de Sousa, R.; Oteo, J.A. Neglected aspects of tick-borne rickettsioses. Parasites Vectors 2018, 11, 263. [CrossRef] [PubMed]

9. Duscher, G.G.; Feiler, A.; Leschnik, M.; Joachim, A. Seasonal and spatial distribution of ixodid tick species feeding on naturally infested dogs from Eastern Austria and the influence of acaricides/repellents on these parameters. Parasites Vectors $2013,6,76$. [CrossRef] [PubMed]

10. Schouls, L.M.; Van De Pol, I.; Rijpkema, S.G.T.; Schot, C.S. Detection and Identification of Ehrlichia, Borrelia burgdorferi Sensu Lato, and Bartonella Species in Dutch Ixodes ricinus Ticks. J. Clin. Microbiol. 1999, 37, 2215-2222. [CrossRef]

11. Bekker, C.P.; de Vos, S.; Taoufik, A.; Sparagano, O.A..; Jongejan, F. Simultaneous detection of Anaplasma and Ehrlichia species in ruminants and detection of Ehrlichia ruminantium in Amblyomma variegatum ticks by reverse line blot hybridization. Vet. Microbiol. 2002, 89, 223-238. [CrossRef]

12. Georges, K.; Loria, G.; Riili, S.; Greco, A.; Caracappa, S.; Jongejan, F.; Sparagano, O. Detection of haemoparasites in cattle by reverse line blot hybridisation with a note on the distribution of ticks in Sicily. Vet. Parasitol. 2001, 99, 273-286. [CrossRef]

13. Rijpkema, S.G.; Molkenboer, M.J.; Schouls, L.M.; Jongejan, F.; Schellekens, J.F. Simultaneous detection and genotyping of three genomic groups of Borrelia burgdorferi sensu lato in Dutch Ixodes ricinus ticks by characterization of the amplified intergenic spacer region between $5 S$ and $23 S$ rRNA genes. J. Clin. Microbiol. 1995, 33, 3091-3095. [CrossRef] [PubMed]

14. Nijhof, A.M.; Bodaan, C.; Postigo, M.; Nieuwenhuijs, H.; Opsteegh, M.; Franssen, L.; Jebbink, F.; Jongejan, F. Ticks and associated pathogens collected from domestic animals in the Netherlands. Vector Borne Zoonotic Dis. 2007, 7, 585-595. [CrossRef]

15. Christova, I.; Van De Pol, J.; Yazar, S.; Velo, E.; Schouls, L. Identification of Borrelia burgdorferi sensu lato, Anaplasma and Ehrlichia species, and spotted fever group Rickettsiae in ticks from Southeastern Europe. Eur. J. Clin. Microbiol. Infect. Dis. 2003, 22, 535-542. [CrossRef] [PubMed]

16. Jado, I.; Escudero, R. Molecular method for identification of Rickettsia species in clinical and environmental samples. J. Clin. Microbiol. 2006, 44, 4572-4576. [CrossRef] [PubMed]

17. Sekeyova, Z.; Roux, V.; Raoult, D. Phylogeny of Rickettsia spp. inferred by comparing sequences of "gene D", which encodes an intracytoplasmic protein. Int. J. Syst. Evol. Microbiol. 2001, 51, 1353-1360. [CrossRef]

18. Fournier, P.; Roux, V.; Raoult, D. Phylogenetic analysis of spotted fever group rickettsiae by study of the outer surface protein rOmpA. Int. J. Syst. Bacteriol. 1998, 48, 839-849. [CrossRef]

19. Roux, V.; Raoult, D. Phylogenetic analysis of members of the genus Rickettsia using the gene encoding the outer-membrane protein rOmpB (ompB). Int. J. Syst. Evol. Microbiol. 2000, 50, 1449-1455. [CrossRef]

20. Labruna, M.B.; Whitworth, T.; Horta, M.C.; Bouyer, D.H.; McBride, J.W.; Pinter, A.; Popov, V.; Gennari, S.M.; Walker, D.H. Rickettsia Species Infecting Amblyomma cooperi Ticks from an Area in the State of Sao Paulo, Brazil, Where Brazilian Spotted Fever Is Endemic. J. Clin. Microbiol. 2004, 42, 90-98. [CrossRef]

21. Black, W.C.; Piesman, J. Phylogeny of hard- and soft-tick taxa (Acari: Ixodida) based on mitochondrial 16S rDNA sequences. Proc. Natl. Acad. Sci. USA 1994, 91, 10034-10038. [CrossRef] [PubMed]

22. Anderson, J.M.J.J.M.; Ammerman, N.C.; Norris, D.E. Molecular Differentiation of Metastriate Tick Immatures. Vector-Borne Zoonotic Dis. 2004, 4, 334-343. [CrossRef] 
23. Estrada-Peña, A.; Nava, S.; Petney, T. Description of all the stages of Ixodes inopinatus n. sp. (Acari: Ixodidae). Ticks Tick Borne Dis. 2014, 5, 734-743. [CrossRef]

24. Estrada-Peña, A.; Gray, J.S.; Kahl, O.; Lane, R.S.; Nijhof, A.M. Research on the ecology of ticks and tick-borne pathogensmethodological principles and caveats. Front. Cell. Infect. Microbiol. 2013, 3, 29. [CrossRef]

25. Gray, J.S. A carbon dioxide trap for prolonged sampling of Ixodes ricinus L. populations. Exp. Appl. Acarol. 1985, 1, 35-44. [CrossRef]

26. Moraes-Filho, J.; Costa, F.B.; Gerardi, M.; Soares, H.S.; Labruna, M.B. Rickettsia rickettsii Co-feeding Transmission among Amblyomma aureolatum Ticks. Emerg. Infect. Dis. 2018, 24, 2041-2048. [CrossRef]

27. Špitalská, E.; Boldišová, E.; Štefanidesová, K.; Kocianová, E.; Majerčíková, Z.; Taragel’ová, V.R.; Selyemová, D.; Chvostáč, M.; Derdáková, M.; Škultéty, L'. Pathogenic microorganisms in ticks removed from Slovakian residents over the years 2008-2018. Ticks Tick Borne Dis. 2021, 12. [CrossRef] [PubMed]

28. Szekeres, S.; Claudia Coipan, E.; Rigó, K.; Majoros, G.; Jahfari, S.; Sprong, H.; Földvári, G. Candidatus Neoehrlichia mikurensis and Anaplasma phagocytophilum in natural rodent and tick communities in Southern Hungary. Ticks Tick Borne Dis. 2015, 6, 111-116. [CrossRef]

29. Takumi, K.; Hofmeester, T.R.; Sprong, H. Red and fallow deer determine the density of Ixodes ricinus nymphs containing Anaplasma phagocytophilum. Parasites Vectors 2021, 14, 59. [CrossRef] [PubMed]

30. Remesar, S.; Díaz, P.; Prieto, A.; García-Dios, D.; Panadero, R.; Fernández, G.; Brianti, E.; Díez-Baños, P.; Morrondo, P.; López, C.M. Molecular detection and identification of piroplasms ( Babesia spp. and Theileria spp.) and Anaplasma phagocytophilum in questing ticks from northwest Spain. Med. Vet. Entomol. 2020, 35, 51-58. [CrossRef]

31. Christova, I.; Schouls, L.; van de Pol, I.; Park, J.; Panayotov, S.; Lefterova, V.; Kantardjiev, T.; Dumler, J.S. High Prevalence of Granulocytic Ehrlichiae and Borrelia burgdorferi Sensu Lato in Ixodes ricinus Ticks from Bulgaria. J. Clin. Microbiol. 2001, 39, $4172-4174$. [CrossRef] [PubMed]

32. Hoepler, W.; Markowicz, M.; Schoetta, A.-M.; Zoufaly, A.; Stanek, G.; Wenisch, C. Molecular diagnosis of autochthonous human anaplasmosis in Austria-An infectious diseases case report. BMC Infect. Dis. 2020, 20, 288. [CrossRef]

33. Kovryha, N.; Tsyhankova, A.; Zelenuchina, O.; Mashchak, O.; Terekhov, R.; Rogovskyy, A.S. Prevalence of Borrelia burgdorferi and Anaplasma phagocytophilum in Ixodid Ticks from Southeastern Ukraine. Vector-Borne Zoonotic Dis. 2021, 21, 242-246. [CrossRef] [PubMed]

34. Zintl, A.; Zaid, T.; McKiernan, F.; Naranjo-Lucena, A.; Gray, J.; Brosnan, S.; Browne, J.; O'Connor, J.; Mee, J.F.; Good, B.; et al. Update on the presence of Ixodes ricinus at the western limit of its range and the prevalence of Borrelia burgdorferi sensu lato. Ticks Tick Borne Dis. 2020, 11, 101518. [CrossRef]

35. Estrada-Peña, A.; Mihalca, A.D.; Petney, T.N. Ticks of Europe and North Africa; Estrada-Peña, A., Mihalca, A.D., Petney, T.N., Eds.; Springer International Publishing: Cham, Switzerland, 2017; ISBN 978-3-319-63759-4.

36. Dunaj, J.; Trzeszczkowski, A.; Moniuszko-Malinowska, A.; Rutkowski, K.; Pancewicz, S. Assessment of tick-borne pathogens presence in Dermacentor reticulatus ticks in north-eastern Poland. Adv. Med. Sci. 2021, 66, 113-118. [CrossRef] [PubMed]

37. Milhano, N.; de Carvalho, I.L.; Alves, A.S.; Arroube, S.; Soares, J.; Rodriguez, P.; Carolino, M.; Núncio, M.S.; Piesman, J.; de Sousa, R. Coinfections of Rickettsia slovaca and Rickettsia helvetica with Borrelia lusitaniae in ticks collected in a Safari Park, Portugal. Ticks Tick Borne Dis. 2010, 1, 172-177. [CrossRef]

38. Mendoza-Roldan, J.A.; Colella, V.; Lia, R.P.; Nguyen, V.L.; Barros-Battesti, D.M.; Iatta, R.; Dantas-Torres, F.; Otranto, D. Borrelia burgdorferi (sensu lato) in ectoparasites and reptiles in southern Italy. Parasites Vectors 2019, 12, 35. [CrossRef]

39. Norte, A.C.; Lopes de Carvalho, I.; Núncio, M.S.; Ramos, J.A.; Gern, L. Blackbirds Turdus merula as competent reservoirs for Borrelia turdi and Borrelia valaisiana in Portugal: Evidence from a xenodiagnostic experiment. Environ. Microbiol. Rep. 2013, 5, 604-607. [CrossRef]

40. Wass, L.; Grankvist, A.; Bell-Sakyi, L.; Bergström, M.; Ulfhammer, E.; Lingblom, C.; Wennerås, C. Cultivation of the causative agent of human neoehrlichiosis from clinical isolates identifies vascular endothelium as a target of infection. Emerg. Microbes Infect. 2019, 8, 413-425. [CrossRef]

41. Garcia-Vozmediano, A.; Krawczyk, A.I.; Sprong, H.; Rossi, L.; Ramassa, E.; Tomassone, L. Ticks climb the mountains: Ixodid tick infestation and infection by tick-borne pathogens in the Western Alps. Ticks Tick Borne Dis. 2020, 11, 101489. [CrossRef]

42. Pedersen, B.N.; Jenkins, A.; Paulsen, K.M.; Okbaldet, Y.B.; Edgar, K.S.; Lamsal, A.; Soleng, A.; Andreassen, Å.K. Distribution of Neoehrlichia mikurensis in Ixodes ricinus ticks along the coast of Norway: The western seaboard is a low-prevalence region. Zoonoses Public Health 2020, 67, 130-137. [CrossRef]

43. Hildebrandt, A.; Gray, J.S.; Hunfeld, K.P. Human Babesiosis in Europe: What clinicians need to know. Infection 2013, 41, 1057-1072. [CrossRef] [PubMed]

44. Bloch, E.M.; Kumar, S.; Krause, P.J. Persistence of Babesia microti Infection in Humans. Pathogens 2019, 8, 102. [CrossRef] [PubMed]

45. Uilenberg, G. Babesia-A historical overview. Vet. Parasitol. 2006, 138, 3-10. [CrossRef] [PubMed]

46. Nováková, M.; Šmajs, D. Rickettsial Endosymbionts of Ticks. In Ticks and Tick-Borne Pathogens; IntechOpen: London, UK, 2019.

47. Kniazeva, V.; Pogotskaya, Y.; Higgs, S.; Krasko, A. The Prevalence of Different Human Pathogenic Microorganisms Transmitted by Ixodes Tick Vectors in Belarus. Vector-Borne Zoonotic Dis. 2021, 21, 6-10. [CrossRef]

48. Szekeres, S.; Docters van Leeuwen, A.; Rigó, K.; Jablonszky, M.; Majoros, G.; Sprong, H.; Földvári, G. Prevalence and diversity of human pathogenic rickettsiae in urban versus rural habitats, Hungary. Exp. Appl. Acarol. 2016, 68, 223-226. [CrossRef] 
49. Hornok, S.; Takács, N.; Szekeres, S.; Szőke, K.; Kontschán, J.; Horváth, G.; Sugár, L. DNA of Theileria orientalis, T. equi and T. capreoli in stable flies (Stomoxys calcitrans). Parasites Vectors 2020, 13, 186. [CrossRef] [PubMed]

50. Hornok, S.; Sugár, L.; Horváth, G.; Kovács, T.; Micsutka, A.; Gönczi, E.; Flaisz, B.; Takács, N.; Farkas, R.; Meli, M.L.; et al. Evidence for host specificity of Theileria capreoli genotypes in cervids. Parasites Vectors 2017, 10, 473. [CrossRef] [PubMed]

51. García-Sanmartín, J.; Aurtenetxe, O.; Barral, M.; Marco, I.; Lavin, S.; García-Pérez, A.L.; Hurtado, A. Molecular detection and characterization of piroplasms infecting cervids and chamois in Northern Spain. Parasitology 2007, 134, 391-398. [CrossRef]

52. Wang, H.; Yang, J.; Mukhtar, M.U.; Liu, Z.; Zhang, M.; Wang, X. Molecular detection and identification of tick-borne bacteria and protozoans in goats and wild Siberian roe deer (Capreolus pygargus) from Heilongjiang Province, northeastern China. Parasites Vectors 2019, 12, 296. [CrossRef]

53. Beck, A.; Huber, D.; Polkinghorne, A.; Kurilj, A.G.; Benko, V.; Mrljak, V.; Reljić, S.; Kusak, J.; Reil, I.; Beck, R. The prevalence and impact of Babesia canis and Theileria sp. in free-ranging grey wolf (Canis lupus) populations in Croatia. Parasites Vectors 2017, 10, 168. [CrossRef] [PubMed]

54. Beck, A.; Huber, D.; Antolić, M.; Anzulović, Ž.; Reil, I.; Polkinghorne, A.; Baneth, G.; Beck, R. Retrospective study of canine infectious haemolytic anaemia cases reveals the importance of molecular investigation in accurate postmortal diagnostic protocols. Comp. Immunol. Microbiol. Infect. Dis. 2019, 65, 81-87. [CrossRef]

55. Fankhauser, B.; Irwin, J.P.; Stone, M.L.; Chester, S.T.; Soll, M.D. Repellent and insecticidal efficacy of a new combination of fipronil and permethrin against stable flies (Stomoxys calcitrans). Parasites Vectors 2015, 8, 4-9. [CrossRef] [PubMed]

56. Yang, Y.; Christie, J.; Köster, L.; Du, A.; Yao, C. Emerging human babesiosis with "ground zero" in North America. Microorganisms 2021, 9, 440. [CrossRef] [PubMed]

57. Rar, V.A.; Epikhina, T.I.; Suntsova, O.V.; Kozlova, I.V.; Lisak, O.V.; Pukhovskaya, N.M.; Vysochina, N.P.; Ivanov, L.I.; Tikunova, N.V. Genetic variability of Babesia parasites in Haemaphysalis spp. and Ixodes persulcatus ticks in the Baikal region and Far East of Russia. Infect. Genet. Evol. 2014, 28, 270-275. [CrossRef]

58. Fuehrer, H.-P.P.; Biro, N.; Harl, J.; Worliczek, H.L.; Beiglböck, C.; Farkas, R.; Joachim, A.; Duscher, G.G. Molecular detection of Theileria sp. ZS TO4 in red deer (Cervus elaphus) and questing Haemaphysalis concinna ticks in Eastern Austria. Vet. Parasitol. 2013, 197, 653-657. [CrossRef]

59. Hornok, S.; Kováts, D.; Csörgi, T.; Meli, M.L.; Gönczi, E.; Hadnagy, Z.; Takács, N.; Farkas, R.; Hofmann-Lehmann, R. Birds as potential reservoirs of tick-borne pathogens: First evidence of bacteraemia with Rickettsia helvetica. Parasites Vectors 2014, 7, 128. [CrossRef]

60. Nosek, J. The ecology, bionomics and behaviour of Haemaphysalis (Haemaphysalis) concinna tick. Z. Parasitenkd. 1971, 36, $233-241$. [CrossRef]

61. Meng, H.; Xu, S.; Yu, Z.; Li, N.; Wang, R.; Gao, X.; Yang, X.; Liu, J. Abundance and seasonal activity of Haemaphysalis concinna (Acari: Ixodidae) at the border between China and Russia in Northern Inner Mongolia, China. Parasites Vectors $2016,9,1$. [CrossRef]

62. Dwużnik, D.; Mierzejewska, E.J.; Alsarraf, M.; Bajer, A. A new focus of the tick Haemaphysalis concinna in Western Poland. Exp. Appl. Acarol. 2019, 78, 93-112. [CrossRef]

63. Kazimírová, M.; Hamšíková, Z.; Špitalská, E.; Minichová, L.; Mahríková, L.; Caban, R.; Sprong, H.; Fonville, M.; Schnittger, L.; Kocianová, E. Diverse tick-borne microorganisms identified in free-living ungulates in Slovakia. Parasites Vectors 2018, 11, 495. [CrossRef] [PubMed]

64. Földvári, G.; Farkas, R. Ixodid tick species attaching to dogs in Hungary. Vet. Parasitol. 2005, 129, 125-131. [CrossRef] [PubMed] 